\title{
Style Sheet for BULLETIN OF CHINESE LINGUISTICS 《中國語言學集刊》稿約及撰稿格式
}

The BULLETIN OF CHINESE LINGUISTICS publishes research in Chinese linguistics with a special focus on historical comparative study and dialectal research. Its areas of interest also include Sino-Tibetan and other languages related to Chinese.

《中國語言學集刊》發表中國語言學領域的學術論文, 即以中國語言、漢藏語或其他與漢語相關 語言為對象之研究成果, 重點尤在歷史比較與方言研究。

The BULLETIN OF CHINESE LINGUISTICS is published as one volume of two issues per year. It does not accept articles that have already been published, or that are being simultaneously submitted to other publications. Articles must be prepared in Microsoft Word format. The Bulletin publishes articles in both English and Chinese. Manuscripts should be single-spaced. Chinese-language manuscripts should be in traditional Chinese characters. Each manuscript should be accompanied by an abstract and keywords in both Chinese and English. Upon receipt, the manuscript is immediately sent out for review. After a manuscript has been published, the author will receive twenty offprints of the article and also one copy of the Bulletin in which the article appears. (Honoraria are not available.)

《中國語言學集刊》為半年期刊。已發表或兩投之文稿恕不接受。稿件必須以中文或英文（單 行）電腦繥寫（英文請用微軟WORD格式, 中文請用繁體字）。文稿須附中、英文提要及關鍵詞。 文稿收悉, 即送外審。凡經審查通過刊載之文稿, 將致贈抽印本二十冊及發表期刊一本, 不另致 酬。

Two sets of manuscripts should be submitted in electronic format (both Word and PDF) to bcl@lfksociety.org. Information such as author name, affiliation, and acknowledgements (if any), should be included in the Word version and omitted in the PDF version, as the latter will be sent out for anonymous review.

兩份稿件須以電子郵件附件（WORD 及 PDF 格式）的方式寄至bcl@lfksociety.org。其中 WORD 文件 包括作者姓名、工作單位、謝啟，PDF 文件則不列作者姓名、工作單位、謝啟。

Initial submissions need not conform to the style sheet requirements. After an article has been accepted for publication, however, it must be revised to so conform. The BULLETIN OF CHINESE LINGUISTICS style sheet generally follows that for the journal Language and Linguistics published by Academia Sinica. Special attention should be paid to the following.

《中國語言學集刊》對初稿並無規定格式要求, 但文稿經審查通過後, 則請作者參照《語言暨語 言學》的體例加以修訂, 並請留意以下各點。

1. Begin article sections with "1" (not zero). Order the sections as follows:

節次從1開始，節中小節次第如下：

1.

1.1

1.1.1

(C) KONINKLIJKE BRILL NV, LEIDEN, 2020 | DOI:10.1163/2405478X-01301012

This is an open access article distributed under the terms of the CC BY-NC 4.O license. 
2. Order examples like this:

舉例編號形式如下 :

(1)

(2) a.

a'. (Use the "straight" quote ['] rather than a "smart" quote ['] or ['] to indicate "prime".)

Give examples consecutive numbers continuing throughout the document; do not renumber from “(1)” for each section of the article.

通篇例句, 編號順序排列。另起一節時, 請勿從頭編號。

3. Use footnotes (not endnotes). An asterisk (*) at the end of the article title will refer to a footnote for acknowledgments; thereafter, all footnotes will be in an uninterrupted, numeric sequence, beginning with “1”.

腳註在當頁下, 通篇腳註, 編號順序排列。謝啟置於所有腳註之前; 並於篇題之後另標星號

(*) 註明。

4. Times New Roman is the working font for journal articles, with italic and bold styles reserved for special marking. Romanization for Chinese examples should be in pinyin. A proliferation of fonts in a document should be avoided.

中文字體請用新細明體, 如需強調則用標楷體。中文例子請用拼音拼寫。如非必要, 請勿雜用 各種字體。

5. Numbering: single digit numbers (1-9) should be spelled out (e.g., one, nine), using numerals for all others. Where many numbers occur within a paragraph or a series of paragraphs, maintain consistency in the immediate context (e.g., 8 out of 12, instead of eight out of 12).

個位數字（1-9）請用英文拼寫（如one, nine），10以上的數字請用阿拉伯數字。在一個段落 或一系列數字，請保持一致（如：8 out of 12，而不是 eight out of 12）。

6. Citation formats: As part of a running text: author (year), or author (year:page)

E.g., Smith (1984), Jones (1999:123)

As a parenthetic note: (author year), or (author year:page)

E.g., (Smith 1984), (Jones 1999:123)

In general, avoid using titles, such as Dr., Professor, or Chairman, and self-referring expressions, such as I, the author, or "in Chan Tai Ming (1990), I propose..."

徵引形式為 “丁邦新（1997）”；凡引述原文時, 引文後需加徵引形式, 兼附頁碼, 如 “（丁 邦新 1997:158) ”。“先生”、“師”、“博士”、“主任” 等稱謂, 如非必要, 一律請免。引用自己著 作時, 請儘量避免使用自我指稱詞語, 如 “我”、“作者”、“在陳大明（1990）, 我已經指出.......” 等等。

7. Sample references: 徵引文獻一律稱 “引用文獻”, 範例如下 :

Anonymous. 1878-1879. Tonic and vocal modification in the Foochow dialect. China Review 7: 182-187.

Baxter, W.H. III. 1977. Old Chinese Origins of the Chinese Chongniu Doublets: A Study Using Multiple Character

Readings. Ph.D. dissertation, Ithaca: Cornell University.

Chomsky, Noam. 1965. Aspects of the Theory of Syntax. Cambridge: MIT Press.

Cowen, William, Michael K. Foster, and Konrad Koerner. (eds.) 1986. New Perspectives in Language, Culture, and Personality: Proceedings of the Edward Sapir Centenary Conference (Ottawa, 1-3 October 1984). Amsterdam and Philadelphia: John Benjamins.

Mattos, Gilbert L. 1988. The Stone Drums of Ch'in. Monumenta Serica Monograph Series 19. Nettetal: Steyler Verlag-Wort und Werk.

Norman, Jerry. 1991. The Min dialects in historical perspective. Languages and Dialects of China, ed. by William

S.-Y. Wang, 325-36o. Journal of Chinese Linguistics Monograph Series Number 3. 
Peyraube, Alain. 1988. Syntaxe Diachronique du Chinois: Évolution des Constructions Datives du XIve Siècle av. J.-C. au XVIIIe Siècle. Paris: Collège de France, Institut des Hautes Études Chinoises.

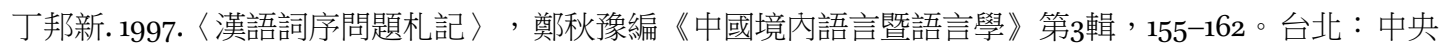
研究院。

李方桂. 1971.〈上古音研究〉，《清華學報》新9.1-2:1-61。

梅祖麟. 1988. 〈詞尾「底」、「的」的來源〉, 《中央研究院歷史語言研究所集刊》59.1:141-172。台北： 中央研究院。

雸錫圭. 1988. 〈關於殷墟卜辭的命辭是否問句的考察〉，《中國語文》1988.1:1-20。又載裁錫圭（1992） 《古文字論集》。北京：中華書局。

趙元任. 1928. 《現代吳語的研究》。北京 : 清華學校研究院。

趙元任, 丁聲樹, 楊時逢, 吳宗濟, 董同䶳. 1948. 《湖北方言調查報告》, 中央研究院歷史語言研究所專刊 之18。上海：商務印書館。

賴惟勤. 1958.〈中古中國語の內・外について〉, 《お茶の水女子大學人文科學紀要》11:31-61。

魏培泉. 1990. 《漢魏六朝稱代詞研究》, 臺灣大學博士論文。

Format for English manuscripts which involve citations from non-English sources:

英文稿件引用非英文文獻範例 :

Chao, Yuen Ren. 趙元任. 1928. 《現代吳語的研究》。北京 : 清華學校研究院。

$\mathrm{Li}$, Rong. 李榮. 1956. 《切韵音系》。北京 : 科學出版社。

Ōta, Tatsuo. 太田辰夫. 1958.《中國語歷史文法》。東京：江南書院。

Yakhontov, S.Е. Яхонтов, Сергей Евгеньевич. 1965. Древнекитайский язык. Москва: Издательство Наука.

Format for Chinese manuscripts which involve citations from works written in different languages by the same author:

中文稿件引用同一作者用不同語言撰寫的著作範例 :

趙元任. 1928. 《現代吳語的研究》。北京 : 清華學校研究院。

Chao, Yuen Ren. 1968. A Grammar of Spoken Chinese. Berkeley: University of California Press. 